\title{
DESAIN DAN STRATEGI PEMBELAJARAN PENDIKAN AGAMA ISLAM PADA PERGURUAN TINGGI UMUM (PTU) DI KOTA MALANG
}

\author{
A. Nurul Kawakip \\ Fakultas Ilmu Tarbiyah dan Keguruan Universitas Islam \\ Negeri Maulana Malik Ibrahim Malang \\ akhmad.nurul@pai.uin-malang.ac.id
}

\begin{abstract}
The paper explores the design and strategy of Islamic teaching (Pendidikan Agama Islam) which where implemented at Tribuana Tungga Dewi University of Malang. The university is consider as fairly a new university, established in 2001, located in the west of Malang. The findings of research are as follow: (1) the design of teaching is based on the actual topics that are based on students needs. (2) the strategies of teaching are applying various strategies such as moving class to some mosques, involving students in Islamic community surrounding of university, and reporting for daily religious activities.
\end{abstract}

Keywords: Religious Activities, Moving Class, Involving In Society Sorrunding The University, and Actual Topics.

Abstrak: Makalah ini mengeksplorasi tentang desain dan strategi penbelajaran Islam (Pendidikan Agama Islam) yang dilaksanakan di Universitas Tribhuana Tungga Dewi Malang. Universitas merupakan sebuah universitas yang baru yang didirikan pada tahun 2001, terletak di sebelah barat kota Malang. Temuantemuan dari penelitian adalah sebagai berikut: (1) Desain pembelajaran didasarkan pada topik yang aktual dan didasarkan pada kebutuhan siswa. (2) Strategi pengajaran yang menerapkan berbagai strategi seperti pindah kelas ke beberapa masjid, melibatkan siswa dalam masyarakat Islam sekitar Universitas, dan melaporkan aktivitas keagamaan sehari-hari.

Kata-kata kunci: Kegiatan Keagamaan, Berpindah Kelas, Masyarakat Sekitar Universitas, dan Topik Yang Aktual. 


\section{Pendahuluan}

Mata kuliah Pendidikan Agama Islam (selanjutnya disebut PAI) pada Perguruan Tinggi Umum (PTU) adalah sebagai mata kuliah wajib yang harus diikuti oleh mahasiswa yang beragama Islam. Dalam konteks ini, tidak ada pengecualian, semua perguruan tinggi di Indonesia, baik negeri maupun swasta, merujuk pada UU Sisdiknas yang dengan jelas dan efektif mewajibkan mahasiswa untuk menempuh mata kuliah agama menurut keyakinnanya sebagaimana dalam UU No. 20 Tahun 2003 tentang Sistem Pendidikan Nasional pasal 37 ayat (1) dan (2). Namun demikian, dalam realitanya, menurut pandangan Mastuhu posisi mata kuliah PAI masih berada pada garis marginal, dalam pengertian mahasiswa masih memandang mata kuliah itu hanya sekedar sebagai mata kuliah supplement atau tambahan. Dalam konteks ini pula, sering kali mata kuliah PAI karena bukan mata kuliah keahlian, maka mahasiswa cenderung tidak mempunyai perhatian yang penuh atau agak meremehkan (Mastuhu, 1995, p. 36).

Padahal ditinjau dari tujuan pelaksanaan Pendidikan Agama Islam di PTU adalah untuk membentuk kepribadian dan karakter mahasiswa terutama jika dikaitkan dengan perilaku yang religius. Jadi mata kuliah PAI tidak hanya ditujukan agar siswa memahami materi ajaran Islam semata-mata, akan tetapi lebih dari itu, mahasiswa diharapkan dengan menempuh mata kuliah PAI, tertanam pula nilainilai ajaran Islam. Singkatnya, materi ajaran Islam, bukan normativ dan sekedar informasi-informasi tentang ajaran Islam, tetapi PAI diharapkan mampu membentuk karakter mahasiswa sesuai dengan tujuan ajaran Islam.

Dalam konteks penelitian ini, peneliti mengambil objek penelitian Perguruan Tinggi Umum di Kota Malang. Alasan pemilihan kota Malang, karena Malang termasuk kota terbesar kedua di Jawa Timur setelah Surabaya. Dengan posisi sebagai kota kedua terbesar, pada saat yang sama Malang disebut juga kota pendidikan, hal ini dikarenakan setidaknya empat PTN (perguruan tinggi negeri), dan puluhan Perguruan Tinggi Swasta (PTS). Menariknya, selain disebut sebagai kota pendidikan, kota Malang sering disebut juga sebagai salah satu kota tempat tujuan wisata, hal ini tidak mengherankan dikarenakan ada beberapa objek tujuan wisata yang tersebar di kota Malang dan Batu. Atas dasar fenomena ini peneliti tertarik untuk meneliti lebih lanjut pelaksanaan pembelajaran PAI pada Perguruan Tinggi Umum di Kota Malang. Lebih spesifik lagi pada Universitas Tribuana Tunggadewi (UNITRI) Kota Malang. Alasan pemilihan objek penelitian, diyakini UNITRI mempunyai karakteristik yang unik. Salah satunya adalah lokasi UNITRI yang berada ditengah-tengah 
pemukiman penduduk, yakni Desa Tlogomas, daerah Jalan Telagawarna yang merupakan kawasan atau kampung yang relative baru, dimana dahulunya adalah daerah pertanian sawah yang subur. Diyakini, jumlah mahasiswa lebih banyak, daripada penduduk Desa Tlogomas. Sementara itu mayoritas mahasiswa, berasal dari luar Jawa dan sebagian kecil yang berasal dari Jawa. Begitu pula agama yang dianut, menurut data sebagian besar mahasiswa beragama non-muslim (Qomarudin, 2016). Dari perspektif pelaksanaan PAI, dalam pandangan Imam Bawani (1998), pelaksanaan PAI di PTU menghadapi banyak tantangan, hal ini sebagaimana dikemukan :

" kemungkinan dari heterogenya fakultas dan program studi yang ada di sebuah perguruan tinggi, maka perlu adanya penjabaran dalam kurikulum PAI yang kemudian direalisasikan secara bertahap pada tujuan pembelajaran sehari-hari. Jadi ada tujuan ahir yang menggambarkan sosok manusia ideal menurut ajaran Islam, diupayakan perwujudannya melalui tujuan institusional pada level perguruan tinggi umum. Lebih lanjut, dilakukan spesialisasi tujuan kurikuler untuk setiap fakultas atau program studi yang ada, dan ahirnya dijabarkan dalam bentuk tujuan pembelajaran yang ingin dicapai di lokal perkuliahan".

Sementara itu dalam pandangan Mastuhu (1999) tentang pelaksanaan pendidikan Islam di PTU, ia mengajukan saran agar mahasiswa didorong dalam pengembangan ilmu pengetahuan dengan lebih dalam merujuk liniaritas keilmuan dengan program studi yang telah mereka pilih. Selanjutnya disertai panduan dan disumberkan pada ajaran-ajaran Islam. Dengan demikian, diharapkan pada ahirnya mata kuliah PAI dapat menyentuh dan menyapa secara metodologis disiplin keilmuan para mahasiswanya yang variatif, sehingga pada gilirannya mereka dapat merasakan kebermaknaannya, baik dalam proses belajar mengajar di kelas maupun pada saat memasuki dunia kerja pada masa yang akan datang.

PAI di PTU juga dianggap belum bermakna, dalam artian dipandang belum efektif dan masih banyak kekurangannya. Hal ini dapat dilihat dari banyaknya keluhan terhadap lulusan perguruan tinggi yang hanya mengetahui soal-soal "normativitas" agama semata namun kesulitan memahami "historitas" agama (Amin Abdullah, 2010). belum lagi masuk kepada persoalan pokok tentang perpaduan antara "ilmu" dan "agama" (al-din wa ulum al-din). Akibatnya PAI justru melahirkan mahasiswa yang berpikiran sempit (dogmatis), ekslusif dengan bidang ilmu yang ditekuni, serta kurangnya toleransi dan 
penghargaan terhadap orang yang berbeda pandangan dan keyakinan. Maka tidak heran jika pada akhirnya sebagian stakeholders (mahasiswa, wali mahasiswa, dan pengguna lulusan) cenderung menjadi apatis dengan PAI di PTU, dan mempertanyakan sejauh mana efektifitas mata kuliah tersebut bagi peningkatan kesadaran mahasiswa baik secara kultural maupun agama. Hal ini sebagaimana dikemukan oleh M. Nafi'

“..menyedihkan sekali pembelajaran PAI di PTU hanya normative dan informative, tidak mampu membentuk karakter mahasiswa. Tengoklah mahasiswa yang belajar di kampuskampus mereka sudah menempuh materi PAI, tetapi kenyataanya aspek pengamalan keagamaan masih kurang memadai" (Kawakib, 2009).

Belum efektifnya pelaksanaan Pendidikan Agama Islam, juga ditengarai dikarenakan kurikulum PAI yang dikembangkan di PTU saat ini belum mampu memenuhi dinamika dan tuntutan zaman. Kurikulum PAI di PTU belum mampu mengatasi permasalahan akibat perkembangan yang ada diantaranya sebagai berikut: (1) perkembangan sosial, politik, budaya, dan agama, (2) perkembangan ilmu pengetahuan dan teknologi yang melaju terlalu cepat, dan (3) perkembangan metodologi. Selanjutnya, pelaksanaan PAI dapat dianalisis dari berbagai perspektif, Pertama, dilihat dari aspek sosial, politik, budaya, ekonomi, dan agama, pelaksanakan pendidikan agama yang berlangsung di sekolah, madrasah, dan perguruan tinggi masih dinilai kurang berhasil. Hal ini dapat dirasakan dari banyaknya kasus korupsi, kolusi dan nepotisme (KKN) yang melanda di berbagai institusi di negeri ini. Masyarakat kita cenderung mengarah pada masyarakat kepentingan (gesellschaft) dan meninggalkan nilai-nilai masyarakat paguyuban (gemeinschaft) sehingga memunculkan konflikkonflik kepentingan, baik kepentingan individu, kelompok, agama, etnis, dan politik (Muhaimin, 2005, p.18).

Selain itu, dekadensi moral dan diabaikannya nilai-nilai ajaran agama juga kian dikeluhkan oleh masyarakat. Permasalahan tersebut menyebabkan pendidikan agama di setiap unit pendidikan baik sekolah maupun perguruan tinggi semakin mendapat sorotan tajam. Kritik yang sering dilontarkan terhadap pendidikan agama saat ini adalah bahwa pendidikan agama tidak berdampak pada perubahan karakter peserta didik. Pendidikan agama tidak mampu mencegah peserta didik berprilaku buruk seperti pergaulan bebas, tawuran, konflik SARA, tindak kriminal, konsumsi minuman keras dan narkoba. 
Masalah dekadensi moral dan gaya hidup yang bertentangan dengan etika dan nilai agama tidak hanya dirasakan oleh masyarakat yang mayoritas penduduknya beragama Islam, tetapi kini sudah mulai dirasakan oleh seluruh negara dibelahan dunia (Muhaimin, 2005).

Kedua, kemajuan IPTEKS saat ini, menyebabkan perubahan global semakin cepat. Hal ini terjadi karena adanya kemajuankemajuan dari negara maju di bidang teknologi informasi dan komunikasi. Harus pula diakui kemajuan IPTEKS mendorong perkembangan berbagai disiplin ilmu termasuk ilmu agama. Namun, kemajuan IPTEKS tersebut masih dipandang sebelah mata dan bahkan ada yang merasa "alergi" dengan kemajuan tersebut. Sehingga, kemajuan IPTEKS belum dapat dimanfaatkan untuk mengembangkan pembelajaran PAI. Di sisi lain, kemajuan IPTEKS telah mempengaruhi bangunan kebudayaan dan gaya hidup manusia. Kenyataan semacam ini akan mempengaruhi nilai, sikap atau tingkah laku kehidupan individu dan masyarakat sehingga masyarakat akan mengalami krisis nilai, kepercayaan, hingga krisis identitas sebagai sebagai suatu bangsa (Muhaimin, 2005).

Ketiga, dalam konteks metodologi, kegiatan pendidikan agama di PTU yang berlangsung selama ini lebih banyak bersifat menyendiri, kurang berinteraksi dengan mata kuliah non-agama. Bahkan adanya anggapan tidak ada kaitan dengan mata kuliah lainnya. Cara pandang seperti ini kurang efektif untuk penanaman perangkat nilai-nilai keagamaan yang komplek. Selain itu kurikulum PAI terlampau padat materi dan terkesan ambisius mengajarkan semua hal, namun sayangnya materi tersebut lebih mengedepankan aspek kognisi (pemikiran) daripada afeksi (rasa) dan psikomotorik (tingkah laku). Begitu juga, Bahan-bahan ajar PAI saat ini belum memadai untuk membangun kesadaran keberagamaan yang utuh dan relevan dengan perubahan sosial yang terjadi di masyarakat. Hasil penelitian Arif Furchan misalnya, kiranya bisa menggambarkan bahwa pembelajaran PAI masih banyak menggunakan cara-cara pembelajaran tradisional, yaitu ceramah monoton dan statis akontekstual, cenderung normatif, dogmatis, monodisipliner, lepas dari sejarah, dan semakin akademis (Furchan, 1993).

Dari uraian tersebut, dapat dipahami bahwa selama ini pembelajaran PAI masih memiliki kelemahan dari pelaksanaannya mulai dari aspek metodologinya yang masih bersifat dikotomis, penyajian materi terkesan bersifat menyendiri (monodisipliner) dan kurang adanya interelasi-interdisipliner dengan mata kuliah yang lain. Selain itu masih banyak kekurangan mulai dari aspek perancangan dan penyusunan kurikulum atau materi yang kurang tepat, orientasi yang 
lebih bersifat teoritis dan kognitif, sempitnya pemahaman terhadap esensi ajaran agama Islam, dan metode pelaksanaan pembelajaran yang cenderung statis. Pembelajaran PAI di PTU juga masih cenderung menggunakan pendekatan normatif, dalam arti pendidikan agama menyajikan norma-norma yang seringkali tanpa ilustrasi konteks sosial budaya sehingga kurang menghayati nilai-nilai agama sebagai nilai yang hidup dalam keseharian apalagi jika dikaitkan dengan profesi yang akan digeluti (Muhaimin, 2004, p. 89).

Untuk memenuhi hal tersebut di atas, dosen PAI di PTU dituntut mampu mengelola proses belajar mengajar yang memberikan tantangan kepada mahasiswa sehingga mau belajar karena memang mahasiswalah subyek utama dalam proses belajar (Usman, 2002, p. 21). Dan selanjuntnya, salah satu upaya untuk meningkatkan kualitas pembelajaran seorang dosen adalah memperbaiki pola pembelajaran dengan menerapkan pendekatan-pendekatan yang dinilai efektif dan efisien untuk diterapkan di kelas (Surakhmad, 2004).

\section{Design Pembelajaran PAI Di Universitas Tribuana Tunggadewi Malang}

\section{Gambaran Umum Universitas Tribuana Tunggadewi.}

Universitas Tribuana Tunggadewi (Unitri) didirikan oleh Yayasan Pendidikan Bhakti Nusantara, Malang melalui dua tahap. Pendirian tahap pertama pada tanggal 14 Desember 1987, sedangkan pendirian pada tahap kedua dilakukan pada tahun 2001, setelah melalui proses yang panjang. Pada tahun 1988 Universitas Tribuana Tunggadewi mulai melakukan kegiatan persiapan pelaksanaan pendidikan di Jl. Besar Ijen 90-92 Malang. Selama kurun waktu 19881989, kegiatan UNITRI hanya mempersiapkan perangkat persyaratan sebuah universitas tanpa menerima mahasiswa baru sambil menunggu ijin operasional dari Direktorar Jenderal Pendidikan Tinggi, Departemen Pendidikan dan Kebudayaan (Qomarudin, 2016).

Berdasarkan SK Mendikbud No.056/0/1990 tanggal 5 Januari 1990, Yayasan Pendidikan Bhakti Nusantara memperoleh ijin dari Menteri Pendidikan dan Kebudayaan untuk menyelenggarakan Sekolah Tinggi Pertanian Tribuana dengan status terdaftar untuk program studi agribisnis, arsitektur pertamanan, teknologi industri pertanian, dan produksi ternak. Pada tahun 1995, program studi agribisnis dan produksi ternak memperoleh status diakui atas dasar SK Dirjen Dikti Departemen Pendidikan dan Kebudayaan No. 451/DIkti/Kep/1995. Pada tahun yang sama Sekolah Tinggi Ilmu 
Ekonomi Tribuana, yang juga dibawah Yayasan Pendidikan Bhakti Nusantara, memperoleh status terdaftar untuk program studi Manajemen dan Akuntansi.

Selama kurun waktu tahun 1990-1997, kegiatan proses perkuliahahn di Sekolah Pertanian dan Sekolah Tinggi Ilmu Ekonomi Tribuana berlangsung di kampus Jalan besar Ijen 90-92, yang merupakan menyewa dari Badan Pendidikan dan Koperasi Mojopahit, Jawa Timur. Berkat upaya keras Yayasan Pendidikan Bhakti Nusantara, selanjutnya Sekolah Pertanian dan Sekolah Tinggi Ilmu Ekonomi Tribuana menempati kampus milik sendiri di Jalan Telaga Warna Blok C Tlogomas Malang. Penggunaan Kampus baru tersebut diresmikan pada tanggal 13 Desember 1997 oleh Gubernur Jawa Timur. Pada tahun 2000, semua program studi pada Sekolah Tinggi Pertanian Tribuana mendapatkan status terakreditasi dari Badan Akreditasi Nasional (BAN), sementara Program studi manajemen dan akuntansi masih proses akreditasi. Selanjutnya berdasarkan SK Menteri Pendidikan Nasional No. 113/D/0/2001 tanggal 2 Agustus 2001,dikembangkan menjadi Universitas Tribunana Tunggadewi dengan 12 Program studi sarjana.

\section{Desain pembelajaran PAI di Universitas Tribuana}

\section{Tunggadewi}

Sebagaimana dikemukakan dimuka bahwa mata kuliah PAI di PTU merupakan mata kuliah wajib yang harus diikuti oleh setiap mahasiswa, terutama yang beragama Islam, atau bagi yang beragama lain yang didasari dengan kesadaran yang tulus dalam mengikutinya (Direktorat Pembinaan Perguruan tinggi Menengah Pertama, 2006). Selanjutnya, sesuai dengan SK No. 38/2002, Dirjen Pendidikan Tinggi tujuan kuliah PAI adalah untuk memeberikan landasan pengembangan kepribadian kepada mahasiswa agar menjadi kaum intelektual yang beriman dan bertakwa kepada Tuhan yang Maha Esa, berbudi pekerti luhur, berfikir filosofis, bersikap rasional dan dinamis, berpandangan luas, ikut serta dalam kerja sama antar umat beragama dalam rangka pengembangan dan pemanfaatan ilmu pengetahuan dan teknologi serta seni untuk kepentingan nasional.

Adapun visi MPK PAI adalah menjadikan ajaran Islam sebagai sumber nilai dan pedoman yang mengantarkan mahasiswa dalam pengembangan profesi dan kepribadian islami. Misinya adalah terbinanya mahasiswa yang beriman dan bertakwa, berilmu pengetahuan, berakhlak mulia serta menjadikan ajaran Islam sebagai landasan berpikir dan berperilaku dalam pengembangan profesi. 
Sedangkan kompetensi dasar mata kuliah PAI adalah menjadikan ilmuwan dan profesional yang beriman dan bertaqwa terhadap Tuhan Yang Maha Esa, berakhlak mulia, dan memiliki etos kerja, serta menjunjung tinggi nilai-nilai kemanusiaan dan kehidupan.

Atas dasar visi, misi, dan kompetensi tersebut, materi pokok PAI di Perguruan Tinggi Umum berdasarkan SK. Dikti Dirjen Depdiknas No. 43 tahun 2006 adalah sebagai berikut.

a. Tuhan Yang Maha Esa dan Ketuhanan.

1) Keimanan dan ketaqwaan

2) Filsafat ketuhanan (Teologi)

b. Manusia

1) Hakikat manusia

2) Martabat manusia

3) Tanggungjawab manusia

c. Hukum

1) Menumbuhkan kesadaran untuk taat hukum Tuhan

2) Fungsi profetik agama dalam hukum

d. Moral

3) Agama sebagai sumber moral

4) Akhlak mulia dalam kehidupan

e. Ilmu Pengetahuan, Teknologi dan Seni

1) Iman, ipteks dan ama! sebagai kesatuan.

2) Kewajiban menuntut dan mengamalkan ilmu

3) Tanggungjawab ilmuwan dan seniman

f. Kerukunan antar umat beragama

1) Agama merupakan rahmat Tuhan bagi semua

2) Kebersamaan dalam pluralitas beragama

g. Masyarakat

1) Masyarakat beradab dan sejahtera 
Nurul Kawakip - Desain dan Strategi Pembelajaran Pendikan Agama Islam Pada

Perguruan Tinggi Umum (PTU) di Kota Malang

2) Peran umat beragama dalam mewujudkan masyarakat beradab dan sejahtera

3) Hak Asasi Manusia (HAM) dan demokrasi

h. Budaya

1) Budaya akademik

2) Etos kerja, sikap terbuka dan adil

i. Politik

1) Kontribusi agama dalam kehidupan berpolitik

2) Peranan agama dalam mewujudkan persatuan dan kesatuan bangsa

Selanjuntya, dalam pandangan dosen PAI UNITRI Visi PAI pada PTS adalah menjadi sumber nilai dan pedoman yang mengantarkan mahasiswa dalam mengembangkan profesi dan kepribadian Islami, sedangkan misi adalah untuk dapat menghasilkan mahasiswa yang bertakwa kepada Allah SWT, menunjukan sikap religius, menjunjung tinggi nilai-nilai kemanusian, menghargai keragaman dan kepedulian terhadap lingkungan berdasarkan ajaran Islam. Dengan Visi dan misi PAI tersebut maka, dosen menyusun materi pada mata kuliah PAI dengan materi yang tematik, artinya lebih mengedepankan masalahmasalah dan pengalaman mahasiswa di luar kelas. hal ini bertujuan, agar apa yang disampaikan oleh dosen, secara teoritis, lebih mudah dipahami karena berkaitan dengan apa yang pernah atau sedang dialami oleh mahasiswa.

Banyak kasus yang dialami oleh mahasiswa, seperti masalah pacaran, berteman dengan teman yang berbeda agama, perbedaan budaya, yang menuntut dosen untuk lebih cermat dalam memberikan jawaban atas permasalahan tersebut, sehingga kuliah dirasa efektif karena mahasiswa tidak kesusahan dalam mencari jawaban atas permsalahan tersebut.

Agama sebagai pedoman hidup seyogyanya dapat memberikan solusi atas permasalahan yang terjadi di masyarakat. mahasiswa merupakan unsur dari masyarakat, yang seharusnya bisa menyelesaikan masalah di tengah masyarakat, baik itu terkait dengan Aqidah, akhlak, Muammalah dan sebagainya.

Dalam implementasinya, apa yang telah digariskan oleh SK Dirjen Dikti tersebut tidak sepenuhnya dapat diterapkan secara penuh. Dalam konteks ini menurut dosen PAI di Universitas Tribuana Tungga 
Dewi, menyatakan problem pelaksanaan PAI di UNITRI sebagai berikut:

\begin{abstract}
" Untuk dosen pengajar PAI, yakni dosen tetap di UNITRI hanya satu, yakni saya sendiri, dua dosen lain, yakni Bapak Djumari adalah sebenarnya statusnya guru di sebuah sekolah, dan Ibu Anis masih baru masuk disini, jadi beliau statusnya dosen tidak tetap. Jadi bisa dibayangkan saya mengajar sekitar 350 atau 400 an Mahasiswa"(Emqi, 2016a).
\end{abstract}

Dari keterangan diatas, kita bisa menarik kesimpulan betapa rasio antara dosen PAI dan mahasiswa masih belum ideal. Dalam kasus ini UNITRI melakukan strategi dengan jalan merekrut guru agama di Sekolah untuk dijadikan pengajar/dosen di Universitas. Sebuah cara mengatasi persoalan dengan cara pragmatis, yang penting ada personal yang mengajar. Padahal tugas guru agama dan dosen PAI jelas mempunyai tantangan yang berbeda. Bisa diduga guru yang merangkap sebagai dosen di UNITRI tidak bisa fokus mengajar, karena kesibukan utama sebagai guru dan kepala sekolah. Selanjutnya, terkait dengan upaya mengatasi problem tersebut, Muh. Fauzi Emqi menuturkan design pembelajaran PAI di UNITRI sebagai berikut:

“...Dalam pandangan saya, mengingat masing-masing perguruan tinggi dan jurusan pada tiap fakultas memiliki konsentrasi keilmuan yang berbeda-beda, maka dosen agama Islam harus melakukan penyesuaian design mata kuliah PAI sesuai dengan pertimbangan-pertimbangan tertentu. Misalnya, dosen agama harus menyesuaikan dan mengkaitkan antara materi mata kuliah PAI dengan disiplin ilmu yang dikembangkan di fakultas atau jurusan tempat kuliah PAI diberikan. Karena itu, mata kuliah PAI di UNITRI saya design merujuk pada hal-hal yang actual yang diperlukan mahasiswa dalam kehidupan seharihari, misal persoalan ubudiyah, juga persoalan actual, seperti tema hukum fiqh (Emqi, 2016c)".

Merujuk pada fenomena ini nampaknya pengajaran PAI di UNITRI, lebih menekankan pada kebutuhan mahasiswa. Karena itu menurut penuturan mahasiwa UNITRI selanjutnya menurutkan:

“.. kami memang belum memiliki buku ajar PAI di UNITRI, yang ada materi berdasarkan kesepakatan mahasiswa dan dosen 
merujuk pada kebutuhan mahasiswa. Sekarang buku ajar, masih dalam proses. Jadi bisa diduga materi antara satu kelas dengan kelas lain, mungkin berbeda. Apalagi juga dosennya berbeda.. (Jamal, 2016)".

Pernyataan mahasiswa ini juga oleh mahasiswa lain:

“... materi kuliah tidak ada bukunya, kami belum punya buku teks, tapi tema kuliah adalah tawaran dari dosen dan kami menambahkan lagi, sesuai dengan usulan masing-masing kelas (Yasir, 2016a).

Berdasarkan keterangan-keterangan diatas dapat disimpulkan, bahwa materi PAI di UNITRI antara kelas yang berbeda tidak sama, begitu pula dosen yang berbeda, juga tidak ada panduan buku ajar. Jadi diyakini, materi PAI dikembangkan merujuk pada tema-tema yang dianggap menarik untuk dikaji. Dosen membuat materi sendiri, selanjutnya ditawarkan kepada mahasiswa. Ini langkah yang dianggap pragmatis, guna mensiasati tidak adanya buku ajar atau kurikulum yang disepakati bersama.

\section{Strategi Pembelajaran PAI di Universitas Tribuana Tunggadewi Malang}

Menurut Raka Joni strategi belajar mengajar berarti pola umum perbuatan guru siswa dalam perwujudan kegiatan belajar mengajar (Joni, 1984). Dari pengertian ini dua hal yang perlu dibedakan yaitu kegiatan "siswa belajar" dan "guru mengajar". Siswa belajar membutuhkan strategi belajar yang tepat, hal ini dimaksudkan agar siswa mendapat hasil yang memuaskan. Dalam kontek ini, dalam literature pendidikan Islam, kita bisa mendapatkan beberapa literature yang khusus membahas tentang relasi guru dan murid. Sebut saja karya Hadratus Syekh Hasyim As'yari dalam kitab adab alim wa al muta'alim, al Madzhahib al tarbawy inda al Ghozaly, dan Ta'lim al Muta'alim karya al Zarnuji.

Adapun yang dimaksud strategi pembelajaran dalam penelitian ini adalah pola hubungan antara pengajar dan mahasiswa dalam perwujudan kegiatan belajar dan mengajar, hal ini dimaksudkan sebagai kerangka dasar atau framework untuk tujuan pembelajaran itu sendiri. Karena itu strategi pembelajaran adalah tindakan nyata yang dilakukan untuk memecahkan masalah belajar, sumber belajar dan 
cara mahasiswa belajar agar kecakapan yang menjadi orientasi belajar PAI dapat tercapai secara efektif dan efesien. Dalam konteks penelitian ini, menurut penuturan dosen PAI di UNITRI, strategi pembelajarn di UNITRI adalah sebagai berikut:

"Strategi pembelajaran PAI yang kami gunakan di UNITRI ini adalah mengacu pada pengamalan keagamaan sehari-hari. Misal saya mulai dari hal yang sederhana, contohnya, pada waktu mengikuti kuliah PAI maka saya memisahkan tempat duduk mahasiswa laki-laki dan perempuan. Begitu pula etika berpakaian, saya tanamkan agar memakai pakaian yang pantas, misal yang perempuan waktu kuliah PAI, wajib memakai jilbab". Dan alhamdulilah, dari sini mereka tergugah untuk sepakat dengan aturan ini (Emqi, 2016b).

Dari hasil wawancara diatas, nampaknya dosen PAI berupaya menciptakan atmosfir dan iklim suasana belajar yang islami, secara praktis tanpa melalui konsep-konsep keagaaman, artinya tanpa mengetahui argument dasar perintah untuk memisahkan diri antara laki-laki dan perempuan. Hal ini dilakukan dengan cara praktek sendiri dan kesadaran yang dibangun bersama antara dosen dan mahasiswa. Bagi mahasiswa yang terpenting adalah terciptanya nuansa keagamaan, dan terciptaya iklim belajar merujuk pada etika-etika dan norma keagamaan yang disepakati antara dosen dan mahasiswa. Berikut beberapa strategi pembelajaran PAI di UNITRI:

\section{1).Pelibatan peran serta mahasiswa dalam kegiatan}

\section{keagamaan di masyarakat lingkungan kampus.}

Strategi pelibatan mahasiswa di luar kampus menjadi pilihan pelaksaan PAI di UNITRI, hal ini merujuk pada lokasi waktu pembelajaran PAI yang hanya ditempuh sekali dalam seminggu, selanjutnya dosen PAI menjelaskan:

“...harus disadari yang paling penting pembelajaran PAI di Unitri adalah tujuannya agar mahasiswa bisa mengamalkan ajaran atau nilai-nilai agama Islam, tidak bertujuan mereka menjadikan mereka ahli ilmu-ilmu agama. Karena itu saya juga mengikutkan mahasiswa kegiatan nuansa keagamaan di masyarakat sekitar kampus, saya mengikutkan mahasiswa untuk kegiatan keagamaan di Masjid Miftahul Jannah. Seperti setiap hari kamis, ba'da sholat magrib di Masjid dilanjutkan membaca Surat Yasin dan Surat al Kahfi. Semula kegiatan ini semula hanya untuk mahasiswa saja, ternyata mahasiswi juga 
tertarik untuk mengikuti” (Emqi, 2016b).

Dari keterangan diatas, nampak design strategi pembelajaran juga menarik, karena menggunakan fasilitas masjid diluar kampus. Sebuah strategi yang cerdas, karena penggunaan fasilitas masjid diluar kampus, juga mempunyai dampak ikut memakmurkan masjid di masjid masyakat sekitar kampus. Mereka tidak hanya berperan sebagai penggembira, tetapi mahasiswa menjadi penggerak kegiataan keagamaan. Dan masyarakat di daerah Tlogomas juga merasakan kehadiran mahasiswa muslim di Tlogomas. Hal ini dikemukan salah satu tokoh masyarakat:

" harus diakui kehadiran mahasiswa UNITRI di daerah Telagawarna ini, terutama ya...yang muslim dan juga berlatar Etnis Madura, membuat kegiatan di masjid di kampung ini menjadi semarak. Sholat Jum'at jama'ah jadi banyak. Seandainya tidak ada mahasiswa Madura itu, ya tidak ada yang bisa istiqomah mengumandangkan adzan lima waktu, juga kegiatan tadarus pada Bulan Suci Ramadan. Kalau liburan kampus, kelihatan sekali, jamaah berkurang... untung ada mahasiswa Madura... " (Bunari, 2016).

Dari keterangan diatas, kita bisa menyimpulkan bahwa strategi pembelajaran menciptakan nuansa keagamaan di PTU, tidak cukup dikelas, dan kampus. Selanjutnya, oleh dosen agama UNITRI dilakukan penambahan program keagamaan tambahan, yakni memanfaatkan tempat ibadah (masjid dan musolah) disekitar kampus dan juga menyertakan kegiatan keagamaan di masyakat. Dampaknya disatu sisi, membuat terciptanya aktivitas keagamaan mahasiswa, disisi lain masyakat sekitar kampus merasakan kehadiran mereka juga bermanfaat bagi kegiatan keagamaan. Informasi dari masyarkat, juga dibenarkan oleh salah satu Mahasiswa Unitri yang berasal dari Madura:

“...saya tidak kos, oleh dosen saya dianjurkan untuk mengabdi mengajar anak-anak di TPQ dan tinggal di bilik Masjid Miftahul Jannah Jl. Telaga Warna. Alhamdulilah, saya senang tinggal disini, bisa ikut kegiatan keagamaan. Bersama mahasiswa lain seperti Kak Lutfi, Zeanuri, saya bergiliran untuk adzan sholat lima waktu dan adzan Sholat Jum'at. Dan setiap kamis mahasiswa-mahasiswi UNITRI juga membaca surat Yasin di Masjid Miftahul Jannah (Yasir, 2016b)." 
Nurul Kawakip - Desain dan Strategi Pembelajaran Pendikan Agama Islam Pada Perguruan Tinggi Umum (PTU) di Kota Malang

\section{3) Wisata religius (mengunjungi masjid dan ziarah ke makam tokoh agama).}

Strategi pengajaran dengan memberikan pengalaman langsung juga menjadi pilihan dalam pengajaran PAI di UNITRI. Menurut dosen PAI unitri, hal ini dimaksudkan untuk memnberikan pengalaman spiritual diluar kelas dan kampus. Dalam stretegi ini, memanfaatkan waktu liburan, atau tanggal merah, pada hari efektif kuliah. Stretegi ini dipandang efektif untuk meningkatkan pengalaman spiritual bagi mahasiswa. Pada salah satu materi kuliah PAI, terdapat materi budaya. Untuk lebih mengenal budaya Islam, khususnya di Jawa, maka Dosen PAI mengadakan kegiatan wisata religi setiap tahun. Tujuannya adalah untuk mengenalkan mahasiswa kepada budaya Islam yang ada di daerah Jawa. Sehingga wawasan mahasiswa dapat terbentuk, tidak hanya secara teoritis saja namun juga terbantu secara visual. Harapannya, mahasiswa dapat memahami apa makna yang terkandung dari budaya Islam di setiap daerah, dengan lebih mengenal corak budayanya. Berikut gambar kegiatan ini :

\section{Ziarah di Makam KH. Abdurrahman Wahid dan Maulana Malik Ibrahim}
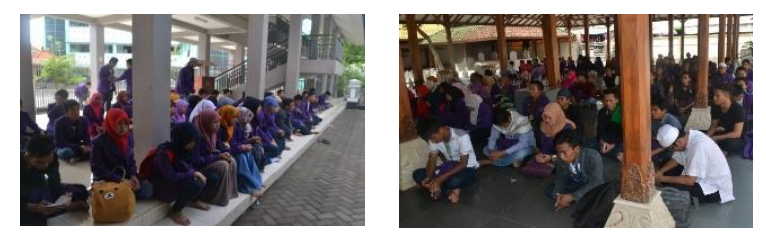

\section{4) Laporan/monitoring Priodik kegiatan keagamaan (Sholat tarawih, Sholat Jum'at, tadarus).}

Salah satu upaya dosen PAI dalam mengembangkan pembelajaran dan pembentukan karakter mahasiswa adalah dengan kartu monitoring. Dosen PAI tidak hanya mengajar dalam kelas, namun juga melakukan pembinaan secara intens kepada mahasiswa di luar kelas. Untuk membantu program pembinaan tersebut, maka diadakan kartu monitoring sebagai syarat untuk mengikuti UAS MK. PAI. Melalui kartu monitoring tersebut, mahasiswa diminta untuk mengikuti kegiatan di luar kampus, terutama kegiatan keagamaan di masjid, seperti pengajian, pembacaan surat Yasin, PHBI dan khatmil Quran. tujuannya, agar mahasiswa dapat lebih bersosialisasi dengan masyarakat dan lebih mengenal lingkungan di sekitar mereka tinggal. 
selain itu, kartu monitoring tersebut juga menjadi indicator kedisiplinan, kejujuran mahasiswa selama melaksanakan pembinaan di luar kampus.

Kartu monitoring tersebut dicetak di kertas warna biru, sebagai antisipasi pemalsuan/plagiasi dari mahasiswa. Hal ini sebagai bahan evaluasi dari kegiatan semester sebelumnya. upaya mahasiswa untuk scanning kartu tersebut bisa dikurangi, karena mahasiswa harus meletakkan foto berukuran $4 \times 6$ di kartu tersebut. kartu tersebut dikumpulkan pada pertemuan akhir perkuliahan, karena harus di check oleh dosen sebelum pelaksanaan UAS. bila tidak lengkap sejumlah 15 kegiatan, hilang atau tidak mengumpulkan maka mahasiswa yang bersangkutan tidak diperbolehkan untuk mengikuti UAS.

\section{5) Materi/Content pembelajaran tematik.}

Dalam pelaksanaan pembelajaran PAI di Unitri, Dosen membagi mata kuliah PAI dalam 2 semester. di semester pertama, acuan pembelajarannya lebih pada masalah aqidah dan akhlak. permasalahan akhlak dianggap perlu dibahas karena pada semester pertama mahasiswa masih baru dan perlu pengenalan terhadap lingkungan mereka tinggal, seperti kos dan kontrakan. Mahasiswa Unitri mayoritas berasal dari luar jawa, sehingga dengan adanya pembelajaran tentang aqidah dan akhlak, maka dosen bisa lebih mengarahkan sikap dan perilaku mahasiswa ketika berhadapan dengan hal-hal baru yang mereka hadapi, terutama budaya yang ada di tempat tinggal mereka.

Disamping hal tersebut, penguatan terhadap aqidah juga dibutuhkan kepada mahasiswa muslim. Unitri memiliki mahasiswa yang berasal dari berbagai daerah, seperti Kalimantan, Papua, NTT, NTB, Sulawesi, Sumatera dan Jawa. Hampir seluruh mahasiswa bermayoritas beragama non muslim (70-80\%) sedangkan yang beragama muslim hanya sekitar 20-30\%. Data tersebut, menuntut dosen mata kuliah PAI untuk lebih intens dalam menguatkan sisi aqidah dari mahasiswa, karena bukan tidak mungkin persinggungan dan pertemuan dari berbagai budaya tersebut akhirnya bisa mempengaruhi keimanan dari mahasiswa di kampus Unitri.

Untuk meningkatkan minat terhadap materi PAI, salah satu stretegi adalah menyusun tema, berdasarkan kesepakatan dengan mahasiswa. Berikut contoh tema materi pangajaran PAI: 
Nurul Kawakip - Desain dan Strategi Pembelajaran Pendikan Agama Islam Pada Perguruan Tinggi Umum (PTU) di Kota Malang

Tabel I : Contoh Materi PAI di UNITRI

\begin{tabular}{|c|c|c|}
\hline No & $\begin{array}{l}\text { Kemampuan Akhir yang } \\
\text { Diharapkan (Kompetensi) }\end{array}$ & Bahan Kajian \\
\hline 1 & $\begin{array}{l}\text { Mendiskripsikan makna agama } \\
\text { Islam dan ruang lingkupnya } \\
\text { Mengemukakan pentingnya agama } \\
\text { Islam dalam kehidupan manusia }\end{array}$ & $\begin{array}{l}\text { Pemahaman Makna Agama } \\
\text { a. Makna agama dan ruang } \\
\text { lingkupnya } \\
\text { b. Urgensi islam bagi } \\
\text { manusia } \\
\text { c. Agama Islam dan Ruang } \\
\text { lingkupnya }\end{array}$ \\
\hline 2 & $\begin{array}{l}\text { - } \text { Mengungkapkan hakikat } \\
\text { ketuhanan dan ketuhanan dalam } \\
\text { Islam } \\
\text { - } \text { Menganalisis pembuktian adanya } \\
\text { tuhan } \\
\text { - Menerapkan nilai-nilai } \\
\text { kebertuhanan } \\
\text { - Mendiskripsi pemikiran/konsep } \\
\text { Kejadian Alam Semesta, } \\
\text { Sunnatullah di Alam Semesta dan } \\
\text { Akhir dari Alam Semesta }\end{array}$ & $\begin{array}{l}\text { Tuhan Dan Alam Semesta } \\
\text { - Hakikat Tuhan, } \\
\text { Pembuktian Adanya } \\
\text { Tuhan dan Konsep Tauhid } \\
\text { - Kejadian Alam Semesta, } \\
\text { Sunnatullah di Alam } \\
\text { Semesta dan Akhir dari } \\
\text { Alam Semesta }\end{array}$ \\
\hline 3 & $\begin{array}{l}\text { - Mengemukakan hakekat manusia } \\
\text { menurut islam } \\
\text { - Membandingkan asal-usul dan } \\
\text { proses manusia menurut islam } \\
\text { dan teori evolusi } \\
\text { - Menjelaskan hubungan status dan } \\
\text { peran manusia sebagai abdullah } \\
\text { dan khalifah } \\
\text { - Melaksanakan tanggungjawab } \\
\text { manusia sebagai abdullah dan } \\
\text { khalifah }\end{array}$ & $\begin{array}{l}\text { Manusia } \\
\text { a. Hakikat Manusia Menurut } \\
\text { Islam } \\
\text { b. Asal-Usul dan proses } \\
\text { penciptaan Manusia } \\
\text { c. Status dan Peran Manusia } \\
\text { sebagai Hamba Allah swt } \\
\text { (Abdullah) } \\
\text { Tanggung Jawab Manusia } \\
\text { sebagai Khalifah Allah swt }\end{array}$ \\
\hline
\end{tabular}

\section{Melibatkan Mahasiswa Dalam Memakmurkan Kegiatan Keagamaan Di Masjid Dengan Tinggal Di Masjid.}

Yang dimaksud point ke strategi ini, adalah dosen PAI menganjurkan dan merekomendasikan mahasiswa untuk tinggal di bilik-bilik atau kamar masjid (Lutfi, Abdurrohim, 2016). Dapat mudah dijumpai masjid-masjid yang ada disekitar kampus UNITRI, hampir dipastikan desain bangunan ada bilik kamar kecil. Setidaknya ada lima 
masjid yang peneliti jumpai menyediakan kamar untuk mahasiswa, hal ini dimaksudkan menfasilitasi mahasiswa yang punya kemampuan seperti mengkumandangkan azan, memberi pelajaran baca tulis alQur'an, bahkan ikut menjaga kebersihan fasilitas masjid. Strategi ini cukup berhasil setidaknya, tidak hanya memakmurkan masjid, tetapi juga memberikan mahasiswa pengalaman untuk berkiprah dalam kegiatan sosial keagamaan di masyarakat. Dan strategi ini mendapat simpati dari masyarakat sekitar masjid, hal ini karena masyarakat merasakan kehadiran mahasiwa UNITRI mampu menyemarakan kegiatan keagamaan warga Tlogomas, khususnya daerah Telaga Warna.

\section{Analisis}

Dari paparan data diatas, peneliti menganalisis bahwa belum ada integrasi keilmuan dan nilai- nilai Islam dalam tataran kebijakan pada masing-masing fakultas di UNITRI. Artinya tema perkuliahan disamakan antar satu fakultas dengan fakultas yang lain. Belum lagi ditinjau dari waktu perkuliahan, diperlukan pendekatan yang berbeda terkait dengan keinginan untuk memenuhi harapan agar internalisasi nilai-nilai agama dapat tercapai. Maka disini, diperlukan kualitas dosen yang mampu memberikan materi perkuliahan dengan waktu yang ada. Karena itu upaya penambahan kegiatan keagamaan diluar kelas, juga menjadi salah satu daya dukung dalam keberhasilan PAI di UNITRI.

Pengembangan tradisi keagaaman atau budaya religius, juga harus mendapat perhatian. Yakni strategi pembelajaran dengan pendekatan pembiasaan. Dosen PAI sudah mewajibkan mahasiswa untuk duduk terpisah antara mahasiswa dan mahasiswi. Begitu pula cara berbusana, maka bagi mahasiswa sudah diwajibkan memakai busana yang pantas atau dipandang menutup aurat. Tradisi ini harus dipertahankan, namun harus terus dijaga standar atau parameter ukuran kepantasan menutup aurat, karena dalam pandangan peneliti masih ada mahasiswi yang memakai jilbab, namun busana ketat, terutama ketika mengikuti perkuliahan. Merujuk pada pembinaan dan penciptaan budaya religi, dalam konteks materi PAI yang diajarkan di UNITRI, maka seharusnya dalam tataran praktek yang ideal dipelajari dan diamalkan secara menyeluruh dan terpadu. Artinya dengan pendekatan ini, maka dalam tataran aplikasinya kurikulumnya berupaya menciptakan proses suasana belajar yang relevan dengan perkembangan usia siswa, kebutuhan siswa dan bermakna bagi kehidupan sehari-hari sebagai seorang muslim (mukalaf).

Sebagai contoh dalam pembelajaran ubudiyah, semisal mengajarkan takbir dalam sholat, pembahasan materi tidak hanya 
berhenti pada letak tangan sewaktu berdiri dalam sholat dan bacaan takbir, tetapi guru juga mengajak siswa untuk dapat mengimplementasikan makna takbir dalam kehidupan sehari-hari siswa. Artinya siswa diajarkan mengucapkan lafadz takbir dengan benar, dan meletakan tangan dengan benar, tetapi juga disertai dengan nilai esensi takbir, yaitu mengecilkan diri kita sebagai manusia yang penuh keterbatasan dan siswa juga diajak untuk membesarkan hanya kepada Allah SWT semata. Ucapan dan ritual gerakan takbir yang benar adalah penting, tetapi esensi takbir (esotoris) untuk diwujudkan dalam kehidupan sehari-hari juga penting.

Jadi kesimpulannya, transfer of knowledge atau yang dhohir (eksotoris) dan yang batin (esoteris) keduanya sama-sama penting. Karena hakikat pendidikan adalah proses transformasi dan internalisasi ilmu pengetahuan dan nilai-nilai pada diri anak melalui penumbuhan dan pengembangan potensi fitrahnya guna mencapai keselarasan dan kesempurnaan hidup dalam segala aspeknya (insan kamil). Dengan pendekatan ini, maka dalam tataran praktis sangat memperhatikan kebutuhan siswa sesuai dengan perkembangan yang holistic dengan melibatkan siswa secara aktif dalam proses pembelajaran baik fisik maupun emosionalnya. Pada ahirnya aktivitas yang diberikan kepada siswa meliputi aktif mencari, menggali, dan menemukan konsep serta prinsip keilmuan holistic, bermakna, dan autentik sehingga siswa dapat menerapkan perolehan belajar untuk memecahkan masalah-masalah yang nyata dan factual didalam kehidupan sehari-hari. Sehinga jika dibuat ilustrasi gambar maka bisa dibuat gambar sebagai berikut :

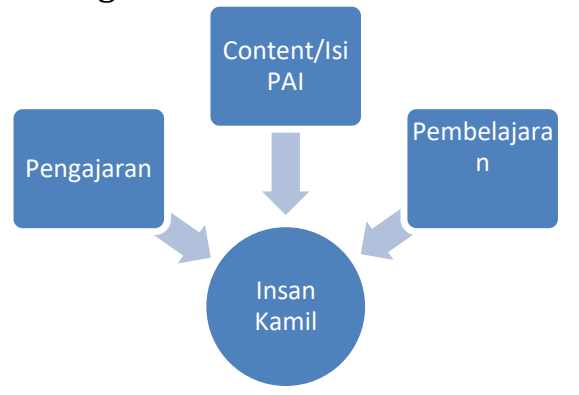

Selanjutnya, dari segi pemahaman terhadap latar belakang keagamaan mahasiswa, nampak ada kesenjangan kemampuan antar mahasiswa. Karena itu seharusnya dosen PAI, melakukan placement test terhadap mahasiswa sebelum mengikuti kuliah PAI. Mahasiswa yang punya latar belakang pendidikan agama yang baik, misal berasal dari lingkungan santri atau berasal dari lulusan pesantren. Mahasiswa ini harus mendapat kelas yang berbeda, artinya tidak disatukan atau 
tidak sekelas dengan mahasiswa yang tidak punya latar belakang keilmuan agama. Dengan ada pemilahan dan klasifikasi kemampuan mahasiswa diharapkan, mahasiswa lebih terdorong untuk belajar lebih baik.

Materi atau content pembelajaran haruslah dinamis, dengan pengertian bahwa dosen mendesain materi menyesuaikan dengan tingkat pemahaman mahasiswa. Dalam konteks ini, maka tidak boleh materi PAI digeneralisasikan, hal ini sekali lagi, karena merujuk pada latar belakang mahasiswa yang variatif. Mahasiswa denga latar belakang minim pengetahuan agamanya, maka harus mendapat perlakuan yang berbeda dengan mahasiswa dengan kemampuan yang sudah memadai.

Sumber daya manusia dalam hal ini dosen PAI di PTU perlu ditingkatkan, baik dari segi kuantitas maupun kualitas. Dalam konteks ini tidak mungkin proses pembelajaran dapat berjalan dengan bagus, kalau hanya mempunyai satu (1) dosen tetap. Karena itu UNITRI memerlukan dosen tetap, mungkin dengan cara mendapatkan dosen tetap PNS untuk membantu di UNITRI, yang disebut dengan istilah dosen DPK.

Selanjuntnya, dalam pengembangan design, peneliti menawarkan konsep merujuk pada pandangan Amin Abdullah dalam mendesain pengembangan akademik menggunakan model interconected entities, yakni dengan mengkaitkan antara ilmu pengetahuan agama dan ilmu pengetahuan umum yang lain. Dalam kontek ini maka masing-masing ilmu diyakini akan keterbatasannya dalam memecahkan persoalan manusia, lalu menjalin kerjasama diantara ilmu-ilmu tersebut setidaknya dalam hal yang menyentuh persoalan pendekatan (approach) dan metode berpikir dan penelitian (process and procedure) (Abdullah, 2010, p. 77). Ilustrasi gagasan tersebut tercermin dalam gambar berikut (Abdullah, 2007):

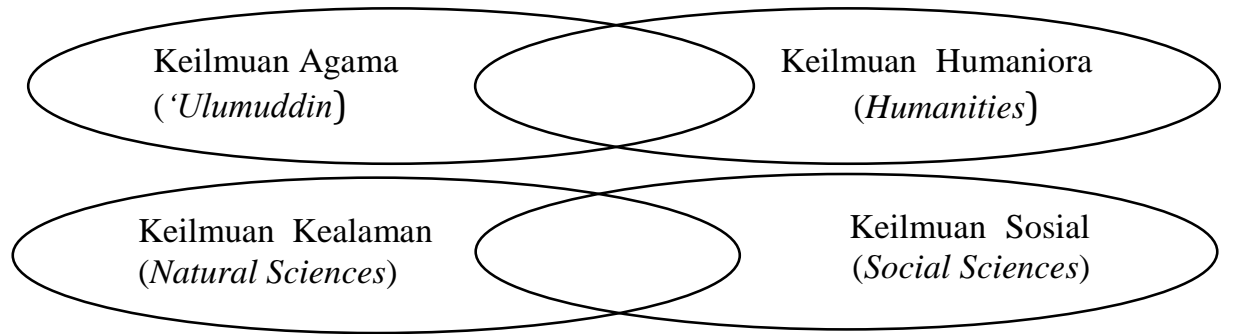

Kaitannya dengan pengembangan kurikulum PAI utamanya di PTU, Kurikulum PAI yang dikembangkan selama ini masih mencerminkan paradigma dikotomis-atomistik yang memandang bidang keilmuannya sebagai disiplin keilmuan mandiri (single entity) 
atau setidaknya menjaga jarak dan kontak dari disiplin-disiplin keilmuan lain (isolated entities). Dalam pandangan peneliti, seharusnya kurikulum PAI yang harus dikembangkan ke depan harus mempunyai semangat integrasi-interkoneksi. Mengkaji satu bidang keilmuan dengan memanfaatkan bidang keilmuan lainnya itulah "integrasi" dan melihat kesalingterkaitan antar berbagai disiplin ilmu itulah "interkoneksi" (Abdullah, 1998). Pendekatan pembelajaran PAI dengan pendekatan intergrasi-interkoneksi yang melibatkan beberapa disiplin ilmu yang relevan disebut dengan pendekatan interdisipliner.

Pendekatan interdisipliner dalam PAI mengandung arti perlunya dialog dan kerjasama antara disiplin ilmu agama dan disiplin ilmu umum yang lebih erat sehingga menjadi satu kesatuan. Singkatnya pada era ilmu pengetahuan ini, PAI tidak boleh lagi menyendiri dan lepas dari ilmu-ilmu kealaman, ilmu-ilmu sosial, dan humaniora. PAI di PTU tidak akan pernah berhasil jika tidak memahami, mempertimbangkan atau mengkontekstualkan dengan politik, ekonomi, sosial, budaya, dan seni. Sebab aspek-aspek tersebut memiliki pengaruh yang luar biasa terhadap tampilan kurikulum PAI. Oleh karena itu, dalam menyusun ulang kurikulum, silabi serta bahan ajar PAI harus dikembangkan dengan menyertakan, memanfaatkan, dan mengkaitkan antar berbagai disiplin ilmu (interdisipliner), sehingga mampu memberi kontribusi positif-emansipatif yang nyata dalam kehidupan masyarakat.

Untuk mengembangankan desain dan strategi pembelajaran PAI di PTU dengan pendekatan interdisipliner panelitian ini maka dapat disusun sebuah langkah-langkah kerja sebagai berikut. Berikut alternative langkah-langkah desain PAI :

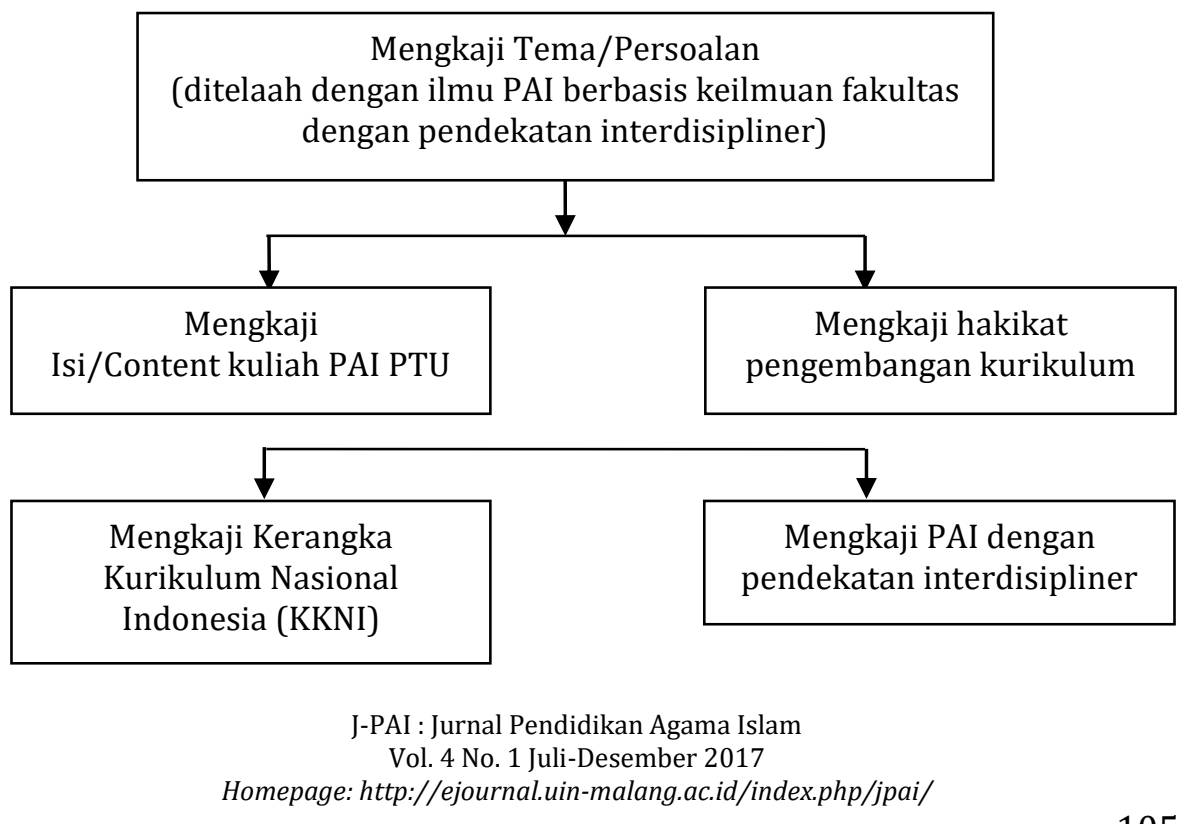


Nurul Kawakip - Desain dan Strategi Pembelajaran Pendikan Agama Islam Pada Perguruan Tinggi Umum (PTU) di Kota Malang

Menetapkan model pengembangan kurikulum (Interdisipliner)

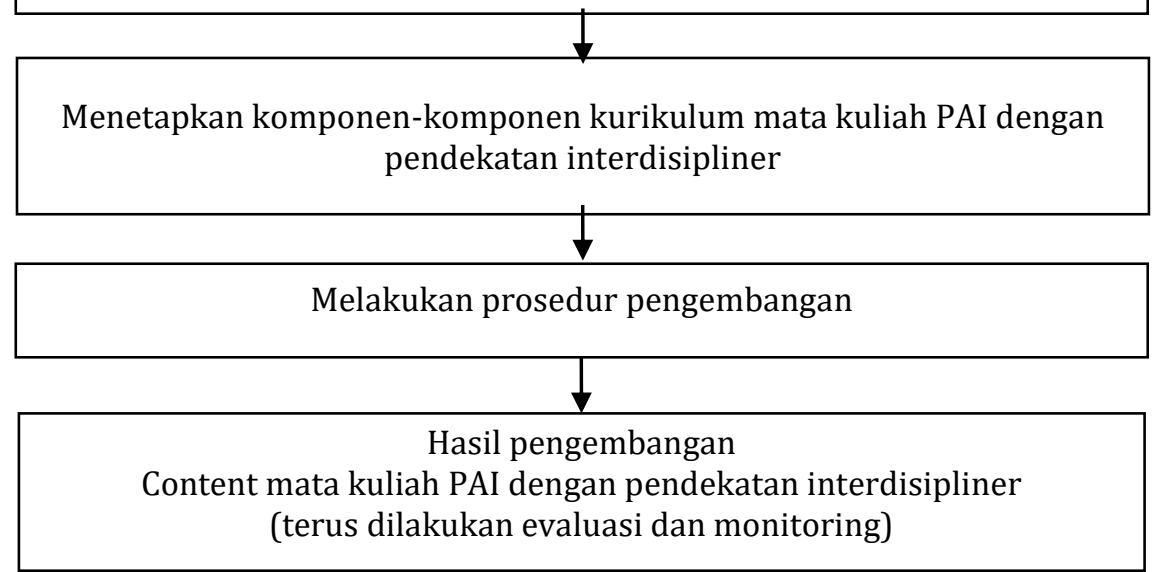

Langkah awal dalam pengembangan desain dan strategi mata kuliah Pendidikan Agama Islam dengan pendekatan interdisipliner bagi mahasiswa UNITRI dengan mengkaji beberapa hal sebagai berikut: (a) visi-misi, profil lulusan, dan capaian pembelajaran yang telah dirumuskan oleh masing-masing program studi di UNITRI, (2) hasil evaluasi kurikulum sebelumnya, (3) pandangan dosen PAI tentang kurikulum PAI dengan pendekatan interdisipliner, dan (4) perkembangan ipteks dan zaman. Hasil kajian tersebut kemudian digunakan untuk mengidentifikasi kebutuhan dengan tujuan mengetahui apakah pengembangan kurikulum dibutuhkan oleh mahasiswa.

\section{Kesimpulan}

1. Design Pengajaran PAI di PTU di Kota Malang, dalam hal ini khususnya di Universitas Tribuatunggadewi (UNITRI) mengacu pada penciptaan iklim dan atmosfir keilmuan agama Islam dan sekaligus pengalaman spiritual. Karena itu design pembelajarannya, tidak terlalu akademis, dalam artian tidak dianjurkan untuk mengkaji dari khazanah bahasa asli (bahasa Arab). Karena itu kajiannya, lebih mengacu pada tematik keagamaan dan persoalan 
yang berkembang di masyarakat. Mahasiswa merasa memerlukan mata kuliah ini, karena mereka sendiri, dibawah bimbingan dosen menentukan tema-tema yang dikaji.

2. Strategi Pembelajarannya, adalah diskusi tematik, moving kelas dan pelibatan peran mahasiswa dibawah bimbingan dosen dalam kegiatan keagamaan baik di Masjid di dalam kampus maupun Masjid di luar kampus. Pembiasaan dan pelaksaan ibadah secara kolektif dan pengalaman spiritual seperti berdizikr, wisata religius, membaca do'a bersama, tadarus adalah strategi pendukung kunci keberhasilan dalam penciptaan pengalaman keagamaan.

\section{DAFTAR PUSTAKA}

Abdullah, M. A. (2007). "Desain Pengembangan Akademik IAIN Menuju UIN: Dari Pendekatan Dikotomis-Atomistik ke IntegratifInterkonektif " dalam Fahruddin Faiz (ed.), Islamic Studies dalam Paradigma Integrasi-Interkoneksi: Sebuah Antologi (Yogyakarta: Penerbit SUKA Press.

------. (2010). Islamic Studies di Perguruan Tinggi, Pendekatan Integrtatifinterkonektif: Yogyakarta: Pustaka Pelajar.

------. (2010). Islamic Studies di Perguruan Tinggi, Pendekatan IntegrtatifInterkonektif, Yogyakarta: Pustaka Pelajar.

Antologi Kajian Islam, (2013). Surabaya: Pascasarjana UIN Sunan Ampel Surabaya.

Bawani, I. (1998) “Metodologi Pendidikan Agama Islam di Perguruan Tinggi Umum," Jurnal IAIN Sunan Ampel: Media Komunikasi dan Informasi Keagamaan, XII.

Bunari, B. (2016, August 5). Tanggapan Masyarakat di daerah Tlogomas.

Direktorat Pembinaan Perguruan tinggi Menengah Pertama, (2006). Panduan Pengembangan Silabus Mata kuliah Pendidikan Agama 
Islam, (Jakarta: Ditjen Manajemen Pendidikan Dasar dan Menengah, Departemen Pendidikan Nasional.

Emqi, M. F. (2016a, June 28). Problem Pengajaran PAI di UNITRI.

Emqi, M. F. (2016b, July 2). Strategi pelibatan mahasiswa di luar kampus menjadi pilihan pelaksaan PAI di UNITRI.

Emqi, M. F. (2016c, July 12). Design Pembelajaran PAI di UNITRI.

Furchan, A. (1993). Developing Pancasilaist Muslims: Islamic Religious Education in Public Schools in Indonesia. Disertasi Doktor tidak dipublikasikan. Australia: La Trobe University Bundorora Victoria.

J. H. Ballantine, (1990). The Sociology of Education .New Jersey: Prentice Hall.

Jamal, J. (2016, June 28). Kebutuhan Mahasiswa Terhadap PAI.

Kamahi, M. B. (2010). Pengembangan Kurikulum Berbasis Interelasi Pendidikan Agama Islam dan Mata Pelajaran Kejuruan di SMK Muhammadiyah 2 Kota Malang. Tesis. Program Studi Manajemen Pendidikan Islam, UIN Maliki Malang.

Kawakib, A. N. (2009). Pesantren and Globalisation. Malang: UIN Maliki Press,.

Kholidah, L. N. (2010). Implementasi Strategi Pembelajaran Mata Kuliah Pendidikan Agama Islam Pada Perguruan Tinggi Negeri Di Surabaya, Disertasi, Program Studi Manajemen Pendidikan, Universitas Negeri Malang.

Mahsun, A. (2010). Pengembangan Kurikulum Pendidikan Agama Islam (PAI) di Universitas Yos Soedarso Surabaya; Problematika dan Alternatif Pemecahannya.ed. M. Ridlwan Nasir, et.al. Surabaya: Pascasarjana IAIN Sunan Ampel.

Mas'ud, A. (2007). Pengantar dalam Model Relasi Guru dan Murid. Yogyakarta: Teras. 
Mastuhu. (1995). "Pendidikan Agama Islam di Perguruan Tinggi Umum", dalam Dinamika Pemikiran Islam di Perguruan Tinggi .Jakarta: Logos Wacana Ilmu.

------. (1999). Memberdayakan Sistem Pendidikan Islam,Jakarta: Logos Wacana Ilmu.

Muhaimin, et. al., (2004). Paradigma Pendidikan Islam: Upaya Mengektifkan Pendidikan Agama Islam Di Perguruan tinggi,Bandung: PT Remaja Rosdakarya.

(1993). Mujib A. Pemikiran Pendidikan Islam: Kajian Filosofis dan Kerangka Dasar Operasional .Bandung: Tri Genda karya.

(2006). Nuansa Baru Pendidikan Islam: Mengurai Benang Kusut Dunia Pendidikan Jakarta: Rajawali Press.

(2005). Pengembangan kurikulum Pendidikan Agama Islam di Sekolah, Madrasah, dan perguruan Tinggi, Jakarta: PT Raja Grafindo Persada.

------. (2009). Rekonstruksi Pendidikan Islam dari paradigm pengembangan hingga manajemen kelembagaan, kurikulum dan strategi pembelajaran. Jakarta: raja Grafindo Persada.

Munip, A. (2008). Perkuliahan Pendidikan Agama Islam di Perguruan Tinggi Negeri; Sebuah Catatan Lapangan, Jurnal Pendidikan Agama Islam Vol. V. No. 1, 15-42.

Mustafa Al-Maraghi, Tafsir al Maraghi Juz 1 .Beirut : Dar al Fikr.

Mustafa Ghoyalain, Idhat al Nasyiin .Surabaya: Salim Nabhan Waaladih, tt.

Nata, A. (2012). Pemikiran Pendidikan Islam dan Barat, Jakarta: Rajawali Press.

Qomarudin, Q. (2016, July 20). Kondisi Geografis Daerah Jalan Telagawarna.

Saksono, G. (2008). Pendidikan Yang Memerdekakan Siswa .Yogyakarta: Rumah Belajar Yabinkas. 
Shihab, M. Q. (1997). Tafsir al Quran al karim, Tafsir atas Surat-surat Pendek Berdasarkan Urutan Turunnya Wahyu .Bandung: Pustaka Hidayah.

Surakhmad, (2004). Pengantar Interaksi Mengajar - Belajar, Bandung: Arsito.

Tafsir, A. (2000). Ilmu Pendidikan Islam .Bandung: Remaja Rosda Karya.

Usman, M. B. (2002). Metodologi Pembelajaran Agama Islam,Jakarta: Ciputat Pers.

Yasir, Y. (2016a, June 28). Kebutuhan Mahasiswa Terhadap PAI.

Yasir, Y. (2016b, August 5). Tanggapan Masyarakat di daerah Tlogomas.

Zaini, A. (July 1998). "Kyai Haji Abdul Wahid Hasyim: His Contribution to Muslim Educational Reform and Indonesian Nationalism during the Twentieth Century", Thesis M.A di Faculty of Graduate Studies and Research, the Institue of Islamic Studies, McGill University, Montreal. 